\title{
Ezeaku Formation Calcarenaceous Sandstone Facies at Abini, Cross River State, Nigeria
}

\author{
Edirin Akpofure and Ayibawari O. Egai
}

\section{ABSTRACT}

Mineralogical and paleocurrent studies of Amasiri Sandstone, a member of Ezeaku Group outcropping as a ridge in Abini were done to determine the quantitative values of component minerals for proper designation of the facies of sandstone and the direction of paleocurrent. Sampling, paleocurrent measurements, petrographic and X-ray diffraction (XRD) analyses were employed to achieve results. Three highly indurated beds of white fine - medium, angular - subrounded grained sandstones were observed. The basal and second beds had thin laminations, whereas the third was massive. The sandstone is found to be hybrid facies, it is not a quartz arenite neither a calcareous sandstone. Calcite $(\mathrm{CaCoz})$ is the most abundant mineral ranging from $43 \%-66 \%$, with an average of $51.39 \%$. Calcite is seen occurring as skeletal grains and sparry calcite, corroding, and replacing quartz grains. Quartz $\left(\mathrm{SiO}_{2}\right)$ ranges from $3 \%-37.6 \%$ with an average of $\mathbf{1 7 . 2 2 \%}$, occurring as detrital quartz and authigenic quartz overgrowth. Monocrystalline and polycrystalline quartz occur, with monocrystalline dominating. Feldspars such as albite, plagioclase, sanidine and orthoclase occur, with the potasssic feldspars dominating. Silica, calcite, and iron oxide were the observed cementing materials. The paleocurrent direction is in the SE. The angularity of the grains implies a source area with close proximity. Therefore, the source area could be inferred to be the Oban Massif or and the Cameroun Mountains.

Keywords: Authigenic, Calcarenaceous, Detrital, Hybrid sandstone, Skeletal grains.

\section{INTRODUCTION}

Calarenaceous sandstone is special sandstone that does not fall into the typical classes of sandstones, but it is hybrid between quartz arenite and calcarenitic limestone. They are a mixture of detrital quartz and detrital carbonates [1]. They are characterized by low quartz content and high carbonate grain content. The carbonate grains are typically non-clastic that are derived from within the basin - They are mainly skeletal particles and ooids. Calcarenaceous sandstones contain up to $50 \% \mathrm{CaCO}_{3}$ as carbonate grains. They occur in carbonate producing areas where there is a large influx of terrigeneous clastic. They grade laterally into limestone or purer sandstone [2].

The Amasiri Sandstones is a member of the Ezeaku Group in the Afikpo Syncline, it occurs as series of parallel asymmetric ridges in the syncline. The study area is bounded by latitudes: $\mathrm{N} 5^{\circ} 41^{\prime}$ and $\mathrm{N} 5{ }^{\circ} 42^{\prime}$ and Longitudes: E8 $8^{\circ} 30^{\prime}$ and $\mathrm{E} 8^{\circ} 40^{\prime}$ (Fig. 1).

The study was centered on the Amasiri Sandstone ridge in Abini, Cross Rivers State, which trends $310^{\circ} \mathrm{NW}-\mathrm{SE}$, it is about $8 \mathrm{~m}$ high. It is highly indurated and was observed to be calcarenaceous facies of the Ezeaku Group from this study based on the petrography and XRD analysis used to determine the mineralogy, their quantitative values and accompanying diffractogram.
Published Online: February 23, 2022

ISSN: $2684-446 \mathrm{X}$

DOI : 10.24018/ejgeo.2022.3.1.247

\section{E. Akpofure*}

Niger Delta University, Wilberforce Island, Bayelsa State, Nigeria.

(e-mail: edirinakpofure ${ }^{@}$ yahoo.com)

A. O. Egai

Niger Delta University, Wilberforce

Island, Bayelsa State, Nigeria.

(e-mail: aegai19@yahoo.com)

*Corresponding Author

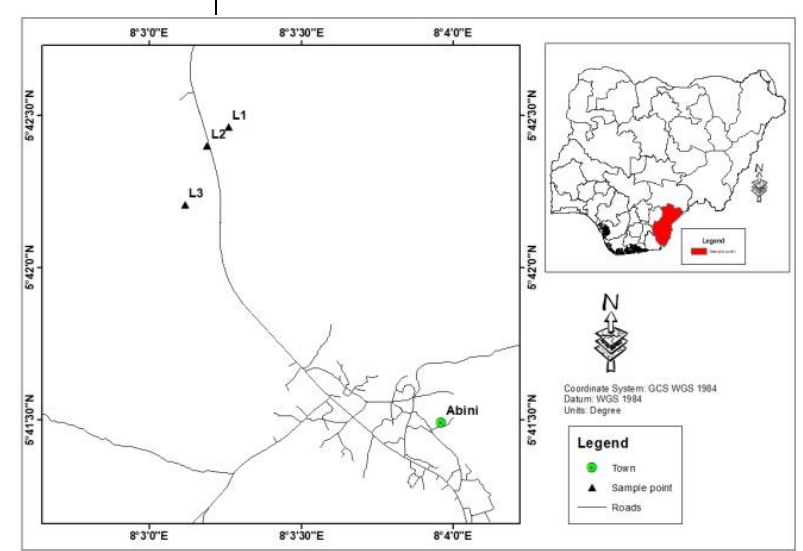

Fig. 1. Location map showing study points.

\section{LITERATURE REVIEW}

Shell D' Archy geologists in the 1950s, studied the Ezeaku Formation, and erected a stratigraphic unit. They described the Formation as hard, flaggy, calcareous grey or black shales and siltstones with impressions of Innoceramus sp. common [3]. [4] Introduced the term "Ezeaku Shale Group" and included all the stratigraphic units deposited in the Late Cenomanian to Turonian in the southern Benue Trough. [5] Subdivided the Ezeaku Formation into several lithofaceies, which are: calcareous and non-calcareous sandstones, siltstones, shales, and limestones. [6] Classified 
the Amasiri Sandstone ridge at Abini as calcareous sandstone with fine to medium grains, fairly sorted and highly bioturbated.

The Ezeaku Formation lies unconformably on the Aptian - Albain Asu River Group. The Ezeaku Formation is made up of calcareous and non-calcareous sandstones, shales and limestones. The outcrop is highly indurated and sedimentary structures such as ripples, swaley cross stratification, planar crossbeds and bioturbation occur. Weathering on exposed surface is also intense giving a reddish colour due to the presence of oxidized iron minerals [7].

\section{STRATIGRAPHY}

Amasiri Sandstone occurs as series of parallel asymmetric ridges in the Afikpo Syncline. The Afikpo syncline is associated with the Benue Trough which is a north east south west trending elongate Cretaceous rift. It is flanked on both sides by Basement rocks. It is believed that much of the lithic fill of the southern Benue Trough are derived from these Basement rocks [8]. Intracontinental conglomerate, sandstone and shales of fluvial origin of the Awi Formation rest on the Basement rock in the Calabar Flank. This was classified with the Asu River Group because of lithological similarities [9]. The first marine transgression deposited the Asu River Group in the Mid-Albian. This is a clastic sequence of shales, limestone, and sandstones. Shales dominate in the south and grade northwards into limestone platforms at Arufu and Gboko [9]. This was followed by a regressive phase that was restricted to the Calabar flank and the Odukpani Group made up of the Ekenkpon Shale and the New Netim Marl were deposited. The second marine transgression which occurred in the Turonian was the most extensive; it deposited the Ezeaku Group and Awgu Formation. In the Anambra basin, the Nkalagu limestone predominates, whereas the Amasiri Sandstone predominates in the Afikpo syncline. The third marine transgression in the Cretaceous stratigraphy of south- eastern Nigeria occurred in the Campanian - Maastrichtian. It deposited the proto Niger Delta Formations in the Anambra basin, Afikpo Syncline and the Nkporo Shale in the Calabar Area. The proto Niger Delta formations include the Nkporo Group, the Mamu Formation, Ajali Formation and the Nsukka Formation in the Cretaceous. The Nkporo Group include: Nkporo Shale and its lateral equivalents: The Afikpo Sandstone in Afikpo syncline, and the Owelli Sandstone and the Enugu Shale in the Anambra basin (See Table I).

\section{Methodology}

The study involved outcrop analysis, paleo-current analysis, sampling of selective beds, petrographic analysis and XRD analysis for mineralogy and modal composition of the Formation. Measurements of inclinations of bed laminae were taken for paleo-current direction. Some of the selected samples were labeled and taken to the laboratory for preparation of thin sections for determination of light minerals by petrographic studies. The rock samples were cut, sliced, and smoothened on one side by carborundum. The slices were put on glass slip with heated basalm on it for the purpose of gluing. For the XRD analysis, the samples received were crushed and split into two equal halves. One crushed portion was pulverized to $100 \%$ passing through $75 \mu \mathrm{m}$ sieve, split into two portions with one portion further submitted for XRD Analysis while the other half was kept as reference sample. The pulverized fraction was analyzed using Rigaku Miniflex 600 XRD equipment employing $\mathrm{Cu}$ $\mathrm{K} \alpha$ radiation at 2 theta angle $2-70^{\circ}$.

TABLE I: STRATIGRAPHIC SUCCESSIONS IN THE ANAMBRA BASIN, AFIKPO

\begin{tabular}{|c|c|c|c|}
\hline Age & Anambra Basin & Afikpo Syncline & Calabar Area \\
\hline $\begin{array}{l}\text { Campanian - } \\
\text { Maastrichtian }\end{array}$ & $\begin{array}{l}\text { Nsukka Formation } \\
\text { Ajali Sandstone } \\
\text { Mamu Formation } \\
\text { Nkporo Group = } \\
\text { Owelli Sandstone/ } \\
\text { Enugu Shale }\end{array}$ & $\begin{array}{c}\text { Nsukka } \\
\text { Formation } \\
\text { Ajali Sandstone } \\
\text { Mamu Formation } \\
\text { Nkporo Group = } \\
\text { Afikpo } \\
\text { Sandstone }\end{array}$ & Nkporo Shale \\
\hline Santonian & & & ??? \\
\hline Coniacian & $\begin{array}{c}\text { Awgu Shale } \\
=\text { Agbani Sandstone }\end{array}$ & & $\begin{array}{c}\text { New Netim } \\
\text { Marl }\end{array}$ \\
\hline Turonian & $\begin{array}{l}\text { Ezeaku Formation = } \\
\text { Nkalagu Limestone }\end{array}$ & $\begin{array}{c}\text { Ezeaku } \\
\text { Formation = } \\
\text { Amasiri } \\
\text { Sandstone }\end{array}$ & $\begin{array}{l}\text { Ekenkpon } \\
\text { Shale }\end{array}$ \\
\hline \multicolumn{4}{|l|}{ Cenomanian } \\
\hline Albian & $\begin{array}{c}\text { Asu River Group = } \\
\text { Abakaliki Shale }\end{array}$ & Asu River Group & $\begin{array}{l}\text { Mfamosing } \\
\text { Limestone } \\
\text { Awi } \\
\text { Formation } \\
\text { [11] }\end{array}$ \\
\hline
\end{tabular}

\section{PRESENTATION AND Discussion of Results}

\section{A. Outcrop Analysis}

The Ezeaku Sandstone ridge located at Abini trends $310^{\circ}$ NW-SE, it is about $8 \mathrm{~m}$ high. It is highly indurated white fine to medium grain sandstone. Three major beds were observed: The basal bed, bed A, is about $0.8 \mathrm{~m}$, it is overlain by thinly laminated bed B of about $1.5 \mathrm{~m}$ thick. The third bed $\mathrm{C}$, which is about $6 \mathrm{~m}$ thick is massive and lies above the thinly laminated bed. The beds dip between $24^{\circ}$ to $50^{\circ}$ NE. See Fig. 2A and 2B.

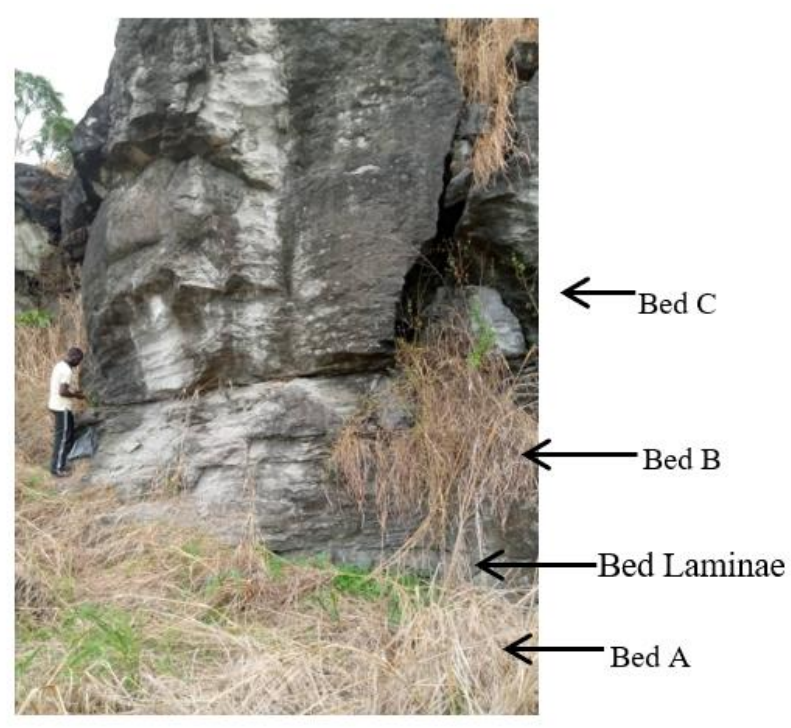

Fig. 2A. Calcarenaceous facies of Amasiri Sandstone at Abini, Cross River State. Nigeria. 


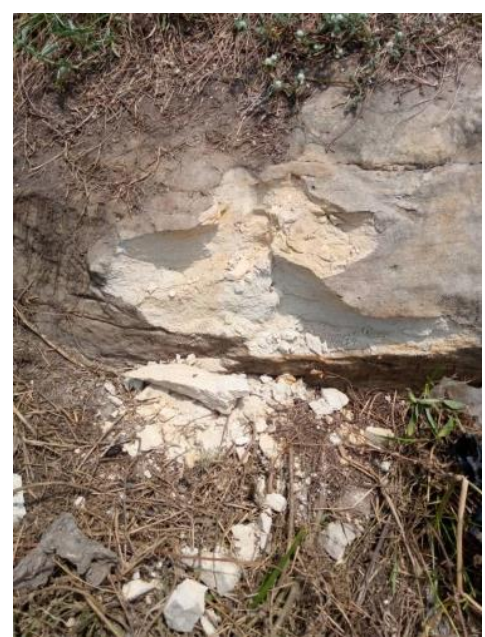

Fig. 2B. Calcarenaceous facies of Amasiri Sandstone at Abini, showing white fine grains.

\section{B. Paleocurrent Analysis}

Paleo-current direction was measured using the inclinations of the laminae in beds $\mathrm{A}$ and $\mathrm{B}$. The following were the azimuth readings, all in the SE direction: 130, 130, $127,131,129,141,142,140,122,125,130,136,122,124$, 130, 131, 130 and132 presented in Table II.

\begin{tabular}{cc} 
TABLE II: FREQUENCY TABLE OF AZIMUTH READINGS \\
\hline Class interval & Frequency \\
\hline $120-129$ & 6 \\
$130-139$ & 9 \\
$140-149$ & 3 \\
TOTAL & $\mathbf{1 8}$ \\
\hline
\end{tabular}

The Sandstone ridge trends $310^{\circ} \mathrm{NW}-$ SE. Fig. 3 shows the rose diagram, which indicates a provenance source in the SE direction. This is suggestive of the Oban Massif and the Cameroun mountains which are in close proximity as the provenance. According to [12], the ridge has been attributed to storm dominated shallow shelf distributary mount submarine bar, and [5] opined that it accumulated along a transgressing Late Turonian - Coniacian epicontinental sea.

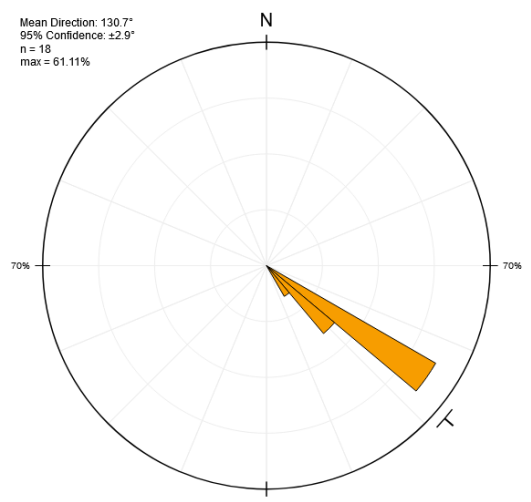

Fig. 3. Rose diagram For Calcarenaceous facies of Amasiri Sandstone in Abini, Cross River State Showing SE paleo-current direction.

\section{XRD Analysis}

The mineralogical assemblage of the Formation was studied using X-ray diffraction (XRD) method. The mineral phases detected by XRD for the various samples are listed in Tables III-IX with their quantitative values and accompanying diffractogram which are shown in Fig IV-X. Calcite is the most abundant mineral ranging from $43-66 \%$, with an average of $51.39 \%$. Quartz $\left(\mathrm{SiO}_{2}\right)$ ranges from 3$37.6 \%$ with an average of $17.22 \%$. Both sodic and potassic feldspars occur, such as Albite, plagioclase, Sanidine and orthoclase with potassic feldspars dominating.

\begin{tabular}{ccc} 
TABLE III: RELATIVE ABUNDANCE OF THE MiNERAL PHASES $(\%)$ AS \\
\multicolumn{3}{c}{ DETERMINED BY XRD ANALYSIS MinERAL } \\
\hline Mineral & Chemical Formula & $\begin{array}{c}\text { ABS } 01 \\
10276(\%)\end{array}$ \\
\hline Calcite & $\mathrm{CaCO}_{3}$ & 53.0 \\
Albite & $\mathrm{Na}_{(\mathrm{AlSi} 3 \mathrm{O} 8)}$ & 2.0 \\
Plagioclase & $\mathrm{Ca}_{0.75} \mathrm{Na}_{0.25} \mathrm{Al}_{1.75} \mathrm{Si}_{2.25} \mathrm{O}_{8}$ & 5.0 \\
Sanidine & $\mathrm{KAlSi}_{3} \mathrm{O}_{8}$ & 19.0 \\
Quartz & $\mathrm{SiO}_{2}$ & 18.0 \\
Muscovite & $\mathrm{KAl}_{2}\left(\mathrm{AlSi}_{3} \mathrm{O}_{10}\right)(\mathrm{F}, \mathrm{OH})_{2}$ & 2.0 \\
Chlorite & $\mathrm{Mg}_{2} \mathrm{Al}_{3}\left(\mathrm{Si}_{3} \mathrm{Al}_{10} \mathrm{O}_{10}(\mathrm{O})_{8}\right.$ & 0.02 \\
Dolomite & $\mathrm{CaMg}_{\left(\mathrm{CO}_{3}\right)}$ & 20. \\
\hline
\end{tabular}

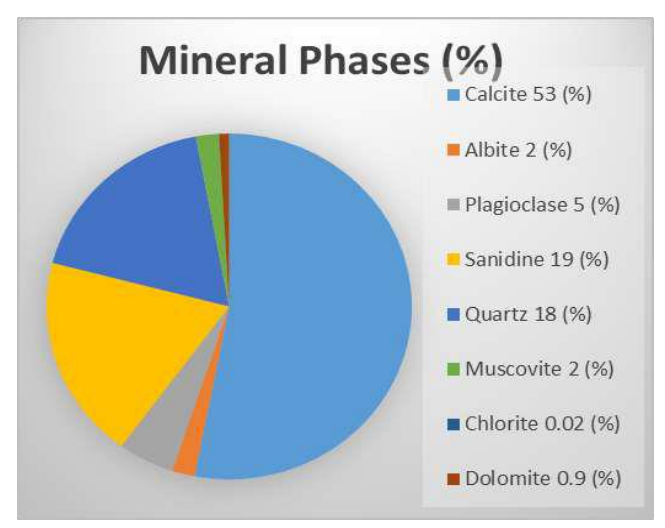

Fig. 4A. Pie chart of mineral phases for ABS 01.

TABLE IV: RELATIVE ABUNDANCE OF THE MiNERAL PHASES (\%) AS

\begin{tabular}{ccc}
\multicolumn{3}{c}{ DETERMINED BY XRD ANALYSIS MINERAL } \\
\hline \multirow{2}{*}{ Mineral } & Chemical Formula & $\mathrm{ABS} \mathrm{02}$ \\
& & $10276(\%)$ \\
\hline Calcite & $\mathrm{CaCO}_{3}$ & 50.0 \\
Quartz & $\mathrm{SiO}_{2}$ & 24.0 \\
Albite & $\mathrm{Na}_{\left(\mathrm{AlSi}_{3} \mathrm{O}_{8}\right)}$ & 9.5 \\
Orthoclase & $\mathrm{Al}_{2} \mathrm{O}_{3} \cdot \mathrm{K}_{2} \mathrm{O}_{6} 6 \mathrm{SiO}_{2}$ & 6.0 \\
Sanidine & $\mathrm{KAlSi}_{3} \mathrm{O}_{8}$ & 5.0 \\
Muscovite & $\mathrm{KAl}_{2}\left(\mathrm{AlSi}_{3} \mathrm{O}_{10}\right)(\mathrm{F}, \mathrm{OH})_{2}$ & 1.0 \\
Chlorite & $\mathrm{Mg}_{2} \mathrm{Al}_{3}\left(\mathrm{Si}_{3} \mathrm{Al}\right) \mathrm{O}_{10}(\mathrm{O})_{8}$ & 0.01 \\
Dolomite & $\mathrm{CaMg}_{\left(\mathrm{CO}_{3}\right)_{2}}$ & 4.0 \\
\hline
\end{tabular}

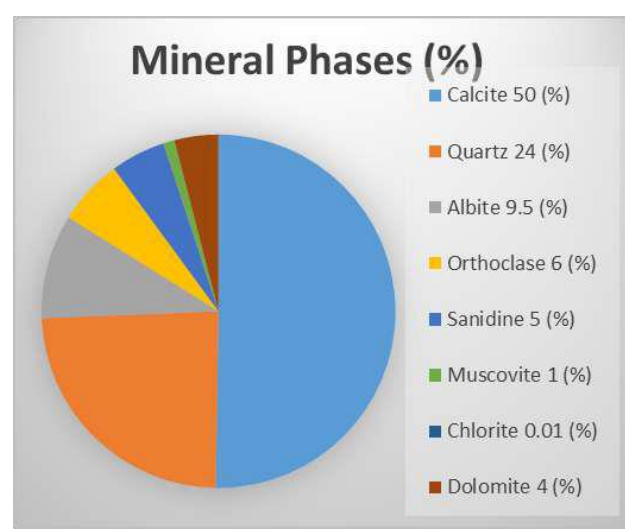

Fig. 4B. Pie chart of mineral phases for ABS 02. 
TABLE V: RELATIVE ABUNDANCE OF THE MinERAL PHASES (\%) AS DETERMINED BY XRD ANALYSIS MINERAL

\begin{tabular}{ccc}
\hline Mineral & Chemical Formula & $\mathrm{ABS} 2 \mathrm{~B}$ \\
& & $10278(\%)$ \\
\hline Calcite & $\mathrm{CaCO}_{3}$ & 50.0 \\
Quartz & $\mathrm{SiO}_{2}$ & 5.4 \\
Albite & $\mathrm{Na}\left(\mathrm{AlSi}_{3} \mathrm{O}_{8}\right)$ & 17.0 \\
Orthoclase & $\mathrm{Al}_{2} \mathrm{O}_{3} \cdot \mathrm{K}_{2} \mathrm{O}_{6} 6 \mathrm{SiO}_{2}$ & 2.3 \\
Sanidine & $\mathrm{KAlSi}_{3} \mathrm{O}_{8}$ & 18.0 \\
Muscovite & $\mathrm{KAl}_{2}\left(\mathrm{AlSi}_{3} \mathrm{O}_{10}\right)(\mathrm{F}, \mathrm{OH})_{2}$ & 3.0 \\
Chlorite & $\mathrm{Mg}_{2} \mathrm{Al}_{3}\left(\mathrm{Si}_{3} \mathrm{Al}\right) \mathrm{O}_{10}(\mathrm{O})_{8}$ & 0.01 \\
Dolomite & $\mathrm{CaMg}_{\left(\mathrm{CO}_{3}\right)_{2}}$ & 5.0 \\
\hline
\end{tabular}

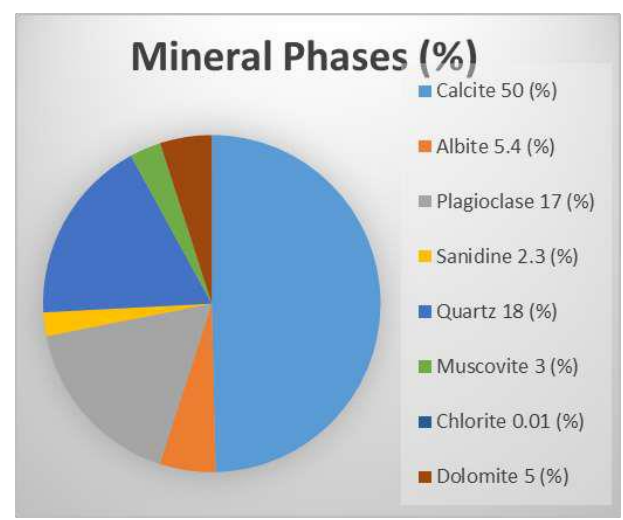

Fig. 4C. Pie chart of mineral phases for ABS 2B.

TABLE VI: RELATIVE ABUNDANCE OF THE MineRAL PHASES (\%) AS DETERMINED BY XRD ANALYSIS MINERAL

\begin{tabular}{ccc}
\hline Mineral & Chemical Formula & $\mathrm{ABS} 4 \mathrm{~B}$ \\
& & $10280(\%)$ \\
\hline Calcite & $\mathrm{CaCO}_{3}$ & 49.0 \\
Quartz & $\mathrm{SiO}_{2}$ & 11.0 \\
Albite & $\mathrm{Na}_{\left(\mathrm{AlSi}_{3} \mathrm{O}_{8}\right)}$ & 17.0 \\
Orthoclase & $\mathrm{Al}_{2} \mathrm{O}_{3} \cdot \mathrm{K}_{2} \mathrm{O}_{6} 6 \mathrm{SiO}_{2}$ & 9.0 \\
Sanidine & $\mathrm{KAlSi}_{3} \mathrm{O}_{8}$ & 5.0 \\
Muscovite & $\mathrm{KAl}_{2}\left(\mathrm{AlSi}_{3} \mathrm{O}_{10}\right)(\mathrm{F}, \mathrm{OH})_{2}$ & 3.0 \\
Chlorite & $\mathrm{Mg}_{2} \mathrm{Al}_{3}\left(\mathrm{Si}_{3} \mathrm{Al}\right) \mathrm{O}_{10}(\mathrm{O})_{8}$ & 0.3 \\
Dolomite & $\mathrm{CaMg}_{2}\left(\mathrm{CO}_{3}\right)_{2}$ & 6.0 \\
\hline
\end{tabular}

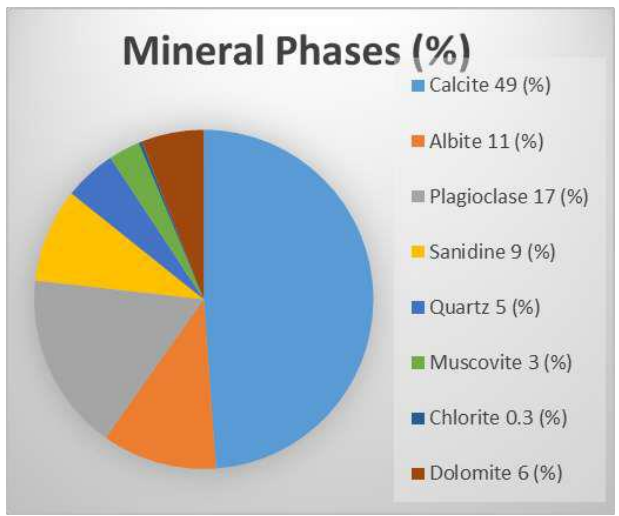

Fig. 4D. Pie chart of mineral phases for ABS 4B.

TABLE VII: RELATIVE ABUNDANCE OF THE MineRAL PHASES (\%) AS DETERMINED BY XRD ANALYSIS MINERAL

\begin{tabular}{ccc}
\hline Mineral & Chemical Formula & $\begin{array}{c}\mathrm{ABS} 5 \mathrm{~B} \\
10281(\%)\end{array}$ \\
\hline Calcite & $\mathrm{CaCO}_{3}$ & 48.7 \\
Quartz & $\mathrm{SiO}_{2}$ & 37.6 \\
Albite & $\mathrm{Na}_{\left(\mathrm{AlSi}_{3} \mathrm{O}_{8}\right)}$ & 1.0 \\
Orthoclase & $\mathrm{Al}_{2} \mathrm{O}_{3} \cdot \mathrm{K}_{2} \mathrm{O}_{6} 6 \mathrm{SiO}_{2}$ & 1.5 \\
Sanidine & $\mathrm{KAlSi}_{3} \mathrm{O}_{8}$ & 9.5 \\
Muscovite & $\mathrm{KAl}_{2}\left(\mathrm{AlSi}_{3} \mathrm{O}_{10}\right)(\mathrm{F}, \mathrm{OH})_{2}$ & 0.8 \\
Chlorite & $\mathrm{Mg}_{2} \mathrm{Al}_{3}\left(\mathrm{Si}_{3} \mathrm{Al}\right) \mathrm{O}_{10}(\mathrm{O})_{8}$ & 0.2 \\
Dolomite & $\mathrm{CaMg}_{\left(\mathrm{CO}_{3}\right)}$ & 0.6 \\
\hline
\end{tabular}

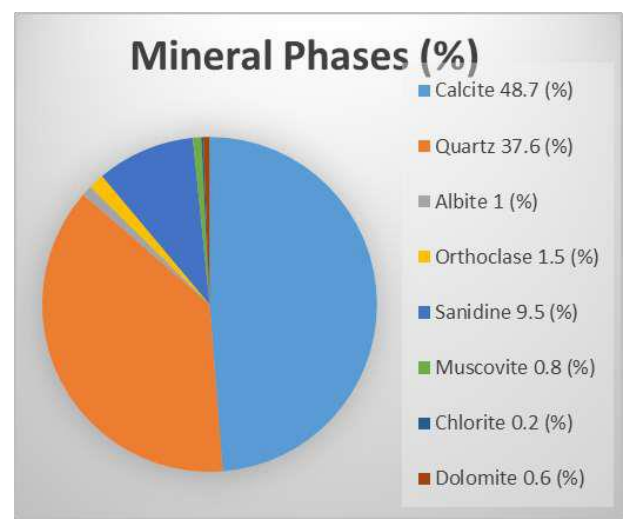

Fig. 4E. Pie chart of mineral phases for ABS 5B.

TABLE VIII: RELATIVE ABUNDANCE OF THE MineRAl PHASES (\%) AS DETERMINED BY XRD ANALYSIS MINERAL

\begin{tabular}{ccc}
\hline Mineral & Chemical Formula & $\begin{array}{c}\text { ABS 5MC } \\
10282(\%)\end{array}$ \\
\hline Calcite & $\mathrm{CaCO}_{3}$ & 43.0 \\
Quartz & $\mathrm{SiO}_{2}$ & 15.0 \\
Albite & $\mathrm{Na}_{\left(\mathrm{AlSi}_{3} \mathrm{O}_{8}\right)}$ & 5.0 \\
Orthoclase & $\mathrm{Al}_{2} \mathrm{O}_{3} \cdot \mathrm{K}_{2} \mathrm{O}_{0} 6 \mathrm{SiO}_{2}$ & 6.0 \\
Sanidine & $\mathrm{KAlSi}_{3} \mathrm{O}_{8}$ & 6.0 \\
Muscovite & $\mathrm{KAl}_{2}\left(\mathrm{AlSi}_{3} \mathrm{O}_{10}\right)(\mathrm{F}, \mathrm{OH})_{2}$ & 9.0 \\
Chlorite & $\mathrm{Mg}_{2} \mathrm{Al}_{3}\left(\mathrm{Si}_{3} \mathrm{Al}_{2} \mathrm{O}_{10}(\mathrm{O})_{8}\right.$ & 2.0 \\
Dolomite & $\mathrm{CaMg}_{\left(\mathrm{CO}_{3}\right)_{2}}$ & 15.0 \\
\hline
\end{tabular}

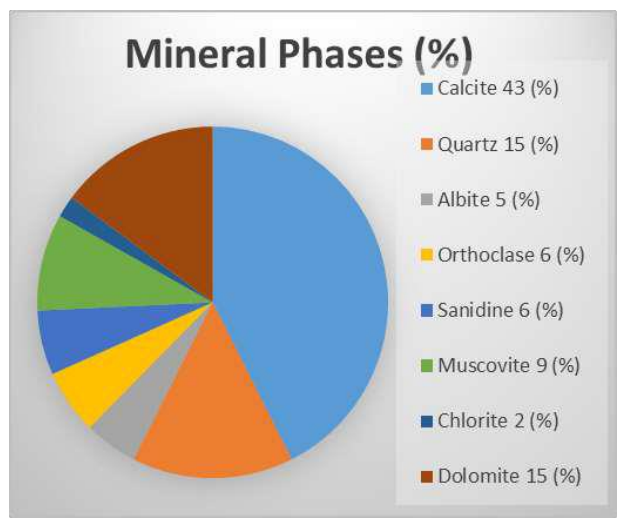

Fig. 4F. Pie chart of mineral phases for ABS 5MC.

\section{Diffractogram of Samples of Amasiri Sandstones in Abini}

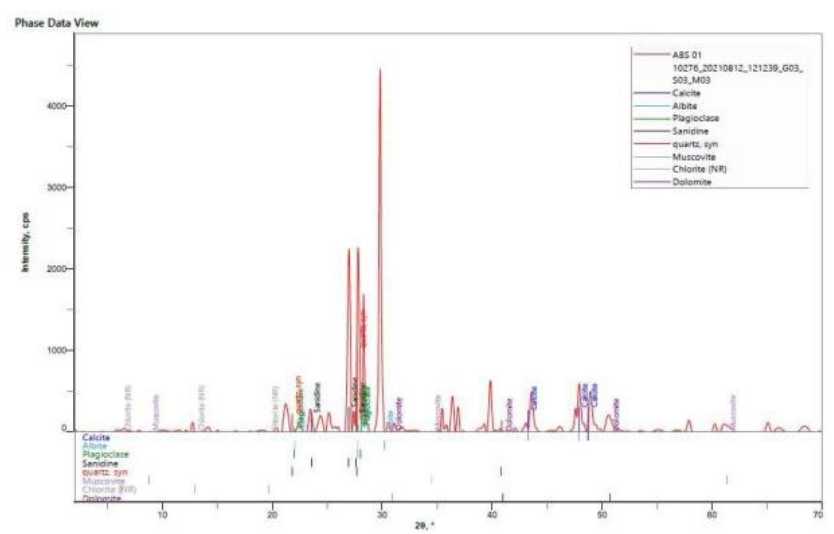

Fig. 5. Diffractogram obtained for ABS 01102276. 


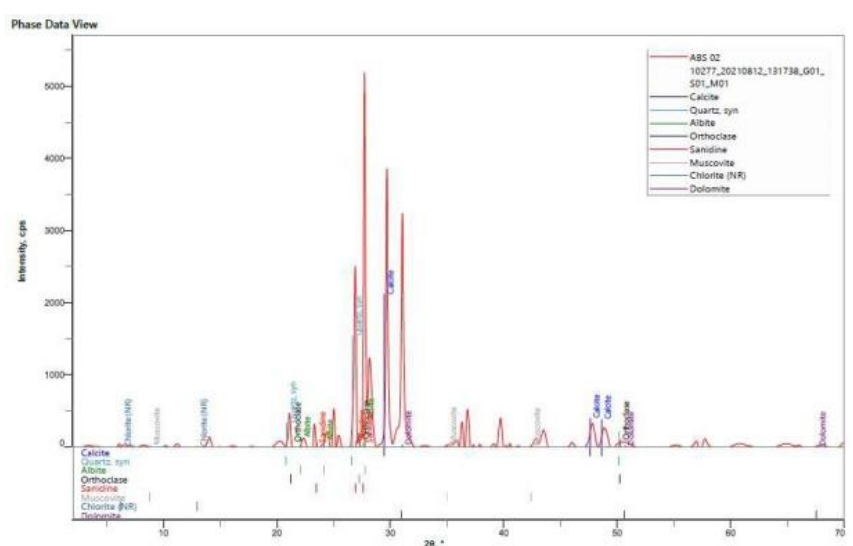

Fig. 6. Diffractogram obtained for ABS 0210277.

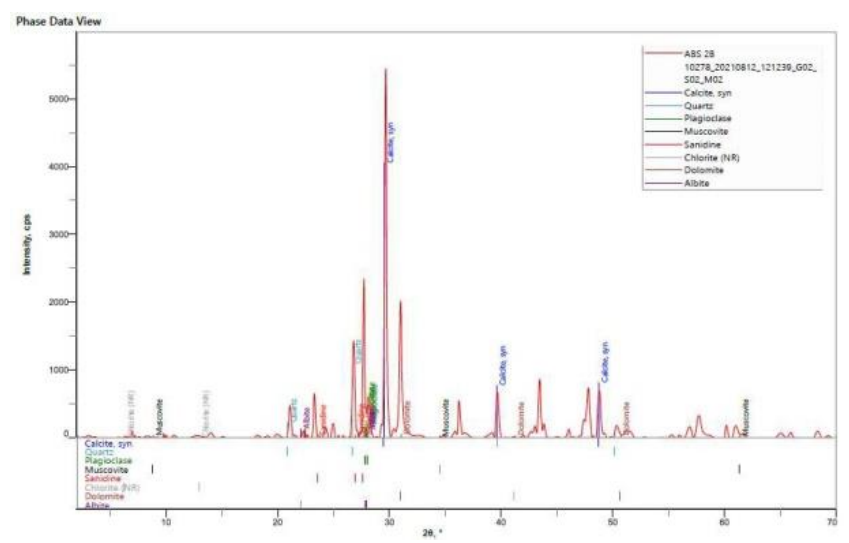

Fig. 7. Diffractogram obtained for ABS 2B 10278.

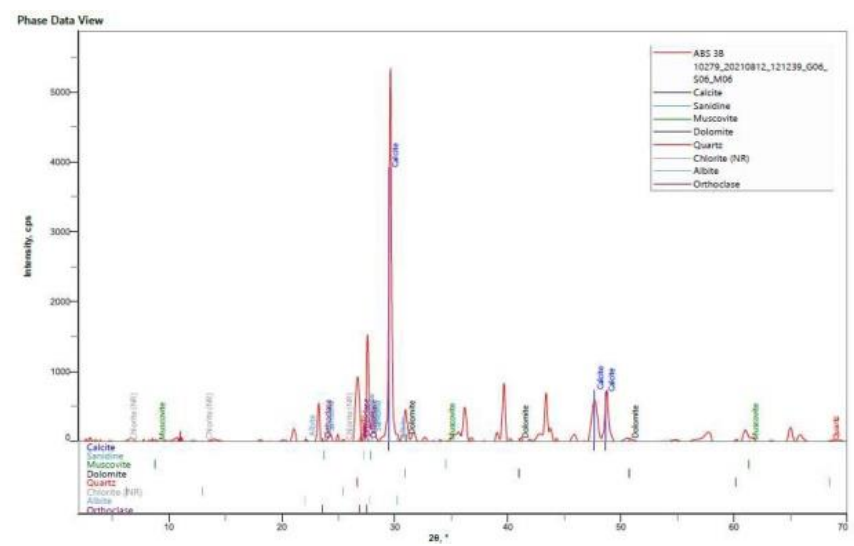

Fig. 8. Diffractogram obtained for ABS 3B 10279.

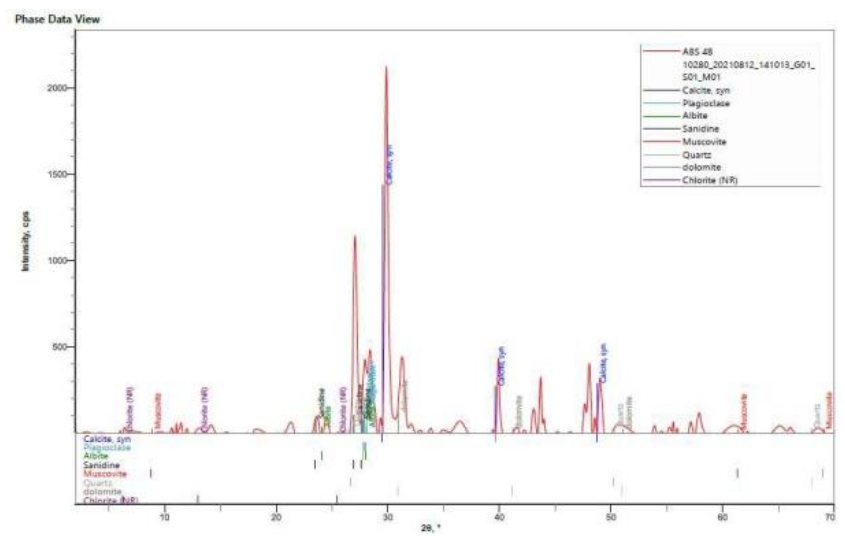

Fig. 9. Diffractogram obtained ABS 4B 10280.

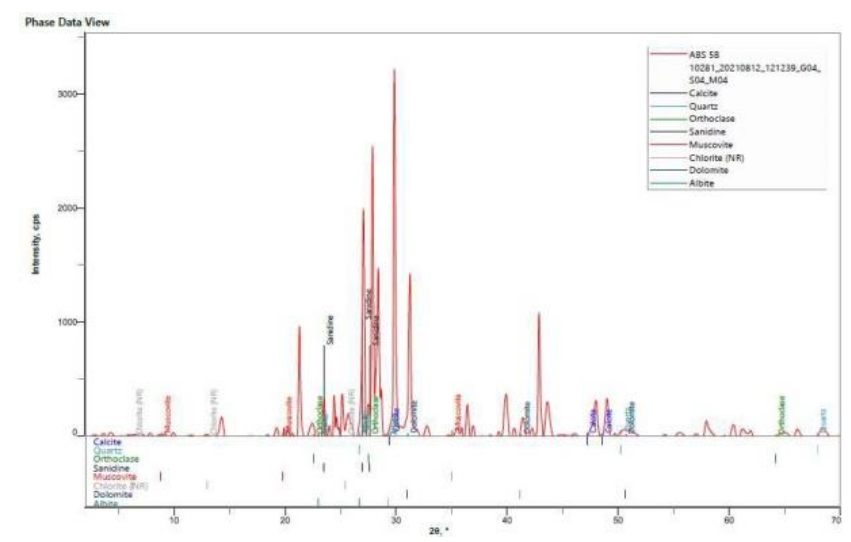

Fig.10. Diffractogram obtained for ABS 5B 10281.

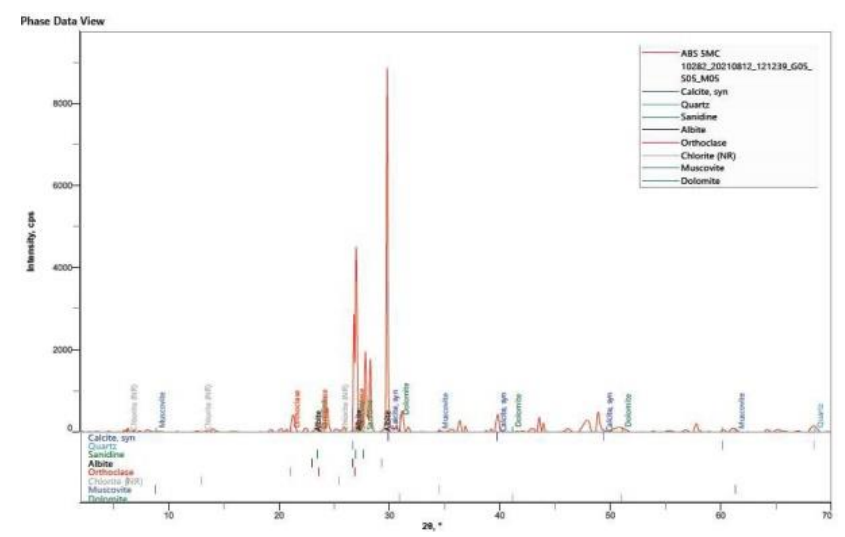

Fig. 11. Diffractogram obtained for ABS 5MC 10282.

\section{PETROGRAPHY}

Under thin sections, it was observed that the Sandstone is made up of fine to medium grains which are elongate, angular to sub-rounded grains of majorly quartz forming the clast, and skeletal particles. See Fig. 11 A-G, which are photomicrographs of the samples under the microscope.

The modal composition of minerals using the Point Counter is given in Table $\mathrm{X}$ and Fig. $12 \mathrm{~A}-\mathrm{G}$. That of quartz is from $15.6 \%$ to $29.6 \%$. The average modal composition is $23.37 \%$. The quartz grains are mainly monocrystaline which show few euhedral quartz overgrowths. The overgrowth is separated from the detrital quartz with a dust rim. It is also observed that some of the edges of the quartz grains are corroded or etched as shown by the irregular embayed contact with calcite, and calcite is seen replacing quartz.

Feldspars were observed but, the potassic feldspars: orthoclase and microcline are most common. They range from $5.6 \%$ to $20.4 \%$. The average modal composition is $13.26 \%$. Rock fragments are not common in the sandstone.

Calcite is seen occurring as skeletal particles and as sparry calcite corroding and replacing quartz grains at grain contacts and within the mineral quartz. The average modal composition is $58.8 \%$

\section{A. Texture}

The grains are fine-medium grains that are poorly sorted. They are sub-angular to sub -rounded, which indicate short distance of travel. The quartz grains are mainly monocrystalline, but, polycrystalline quartz do occur. Targential, sutured and concave-convex grain contacts were 
observed. Also observed were deformational structures such as fractures on the grains.

\section{B. Diagenesis}

Silica cement which may have resulted from the solution and recrystallization at grain contacts occurs as microcrystalline and crystalline aggregates filling pores as well as overgrowth on detrital quartz.

Calcite cement is the most abundant but is more recent than the silica. This is because it fills the pore created by microcrystalline quartz grains and fills the dust rims as alteration products. Iron oxide occurs as coating on the detrital grains. The average modal composition is $4.57 \%$. The sequence of decreasing abundance is in the following order: Calcite, Silica and Iron oxide.

TABLE X: Modal Composition Of SANDSTONE From Point CounTER

\begin{tabular}{ccccc}
\multicolumn{5}{c}{ AT 250X UNDER XPL } \\
\hline Samples & Quartz & $\begin{array}{c}\text { Orthoclase/ } \\
\text { Microcline }\end{array}$ & Calcite & Iron Oxide \\
\hline ABS1 & 28 & 14 & 54.4 & 3.6 \\
ABS2 & 26.8 & 17.2 & 48.4 & 7.6 \\
ABS2B & 15.6 & 10.8 & 70 & 3.6 \\
ABS3B & 19.6 & 5.6 & 68.4 & 6.4 \\
ABS4B & 16.8 & 9.6 & 70 & 3.6 \\
ABS5B & 29.6 & 15.2 & 51.2 & 4 \\
ABS5MC & 27.2 & 20.4 & 49.2 & 3.2 \\
Average & 23.37 & 13.26 & 58.8 & 4.57 \\
\hline
\end{tabular}

\section{Paragenetic sequence}

Textural relationship of the grains and cement in the Formation indicate the following order:

1) Development of iron oxide coating on quartz grains and quartz boundaries.

2) Solution and recrystallization of silica as microcrystalline quartz and quartz overgrowth

3) Calcite development.

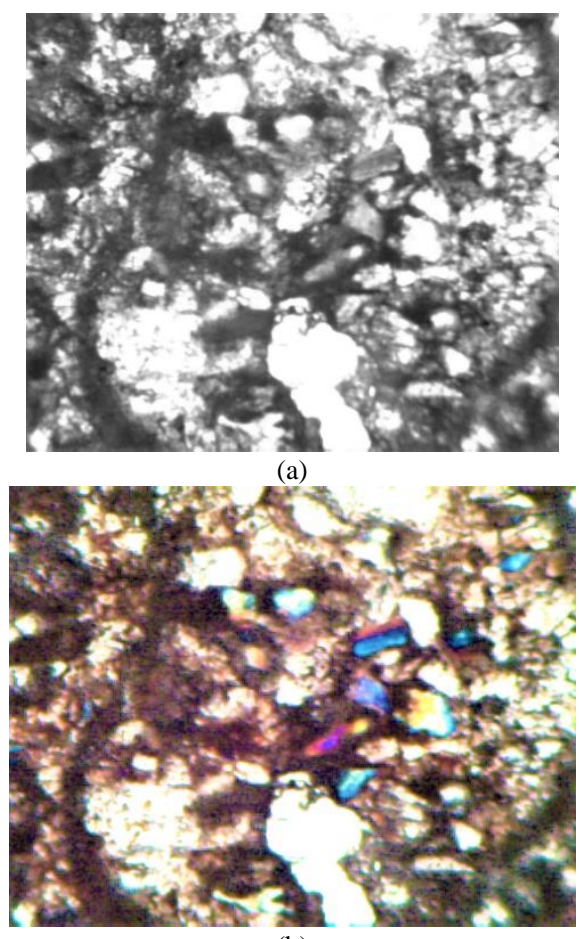

(b)

Fig. 12A. Photomicrograph of ABS 1 under PPL (40X) (a) and XPL (40X) (b).
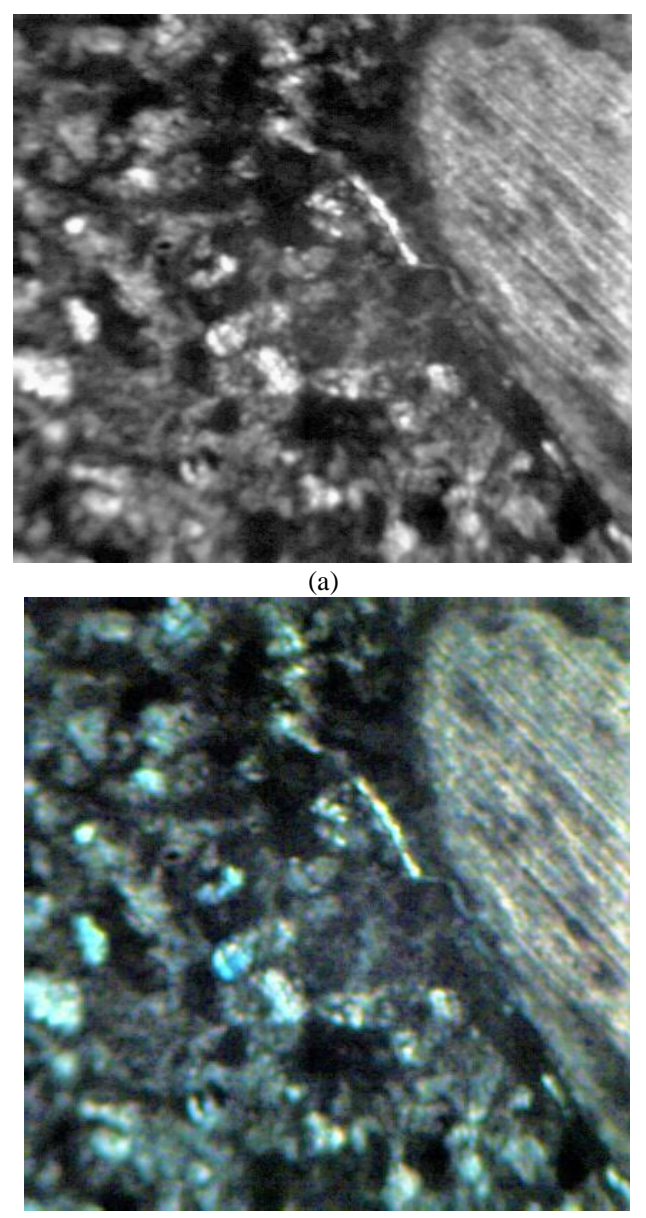

(b)

Fig. 12B: Photomicrograph of ABS 2 under PPL (40 X) (a) XPL (40X) (b).

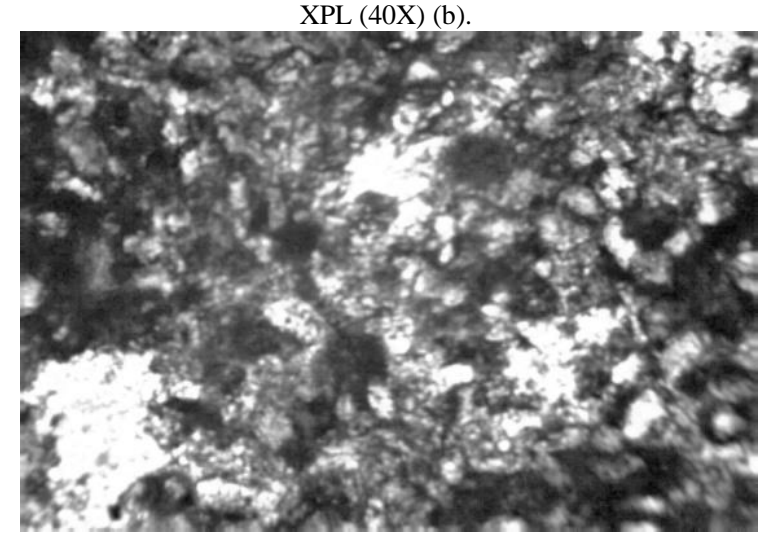

(a)

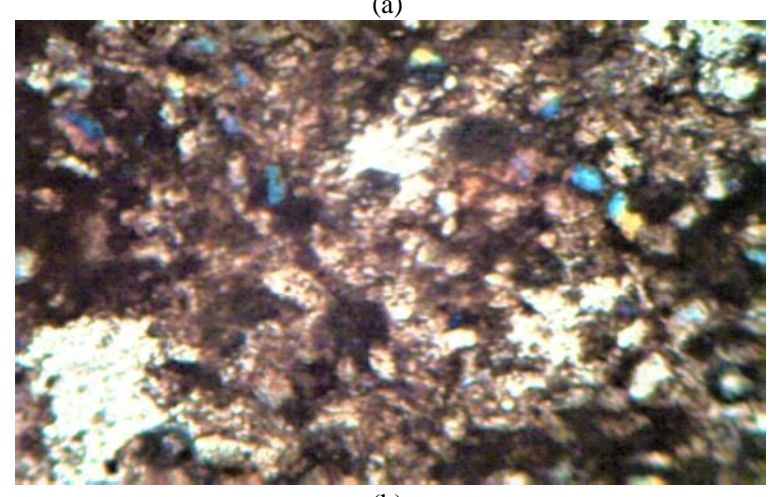

(b)

Fig. 12C. Photomicrograph of ABS 2B under PPL (40X) (a) and XPL (40X) (b). 


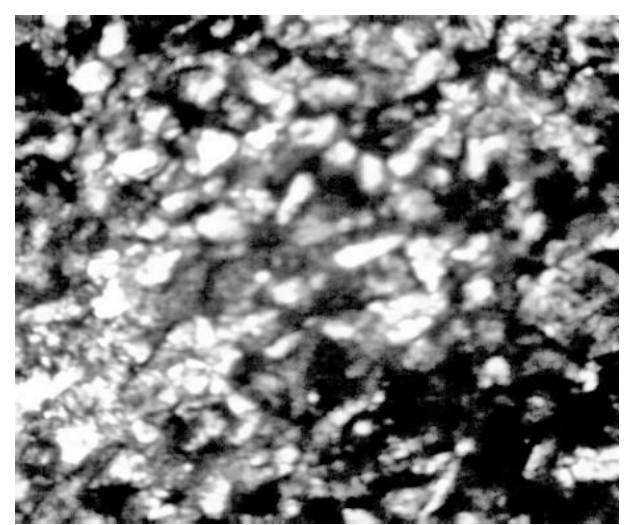

(a)

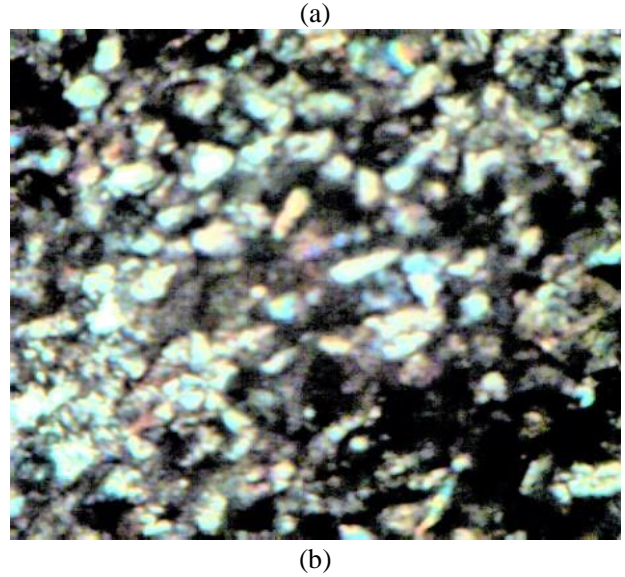

Fig. 12D. Photomicrograph of ABS 3B under PPL (40X) (a) and XPL (40X) (b).

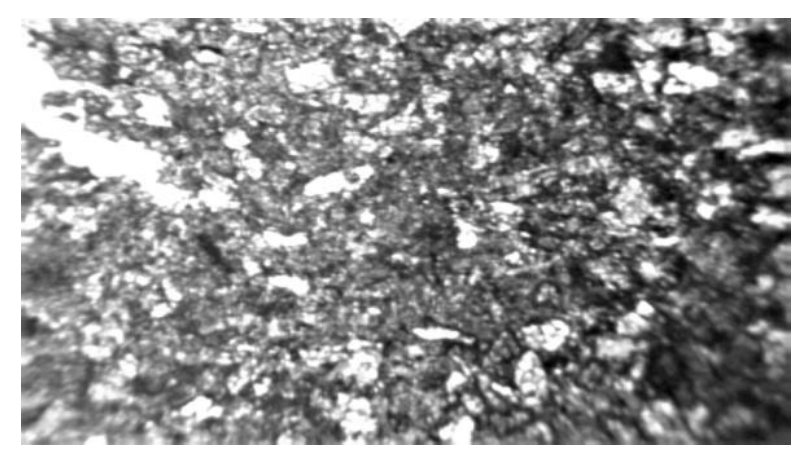

(a)

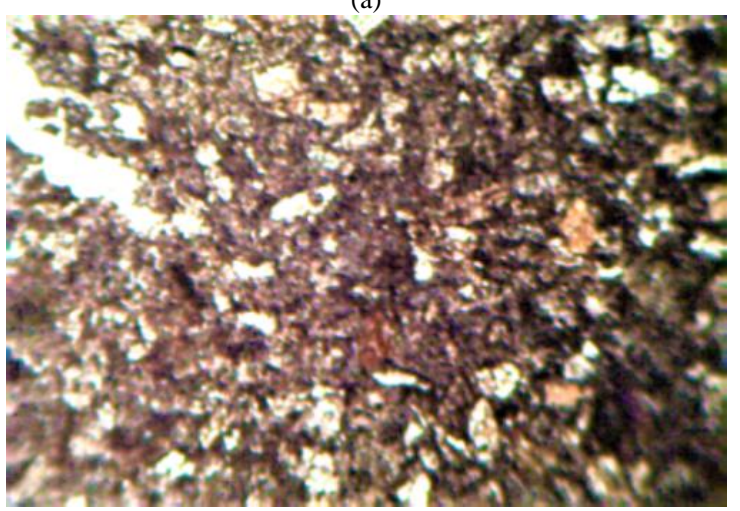

(b)

Fig. 12E. Photomicrograph of ABS 4B under PPL (40X) (a) and XPL (40X) (b).
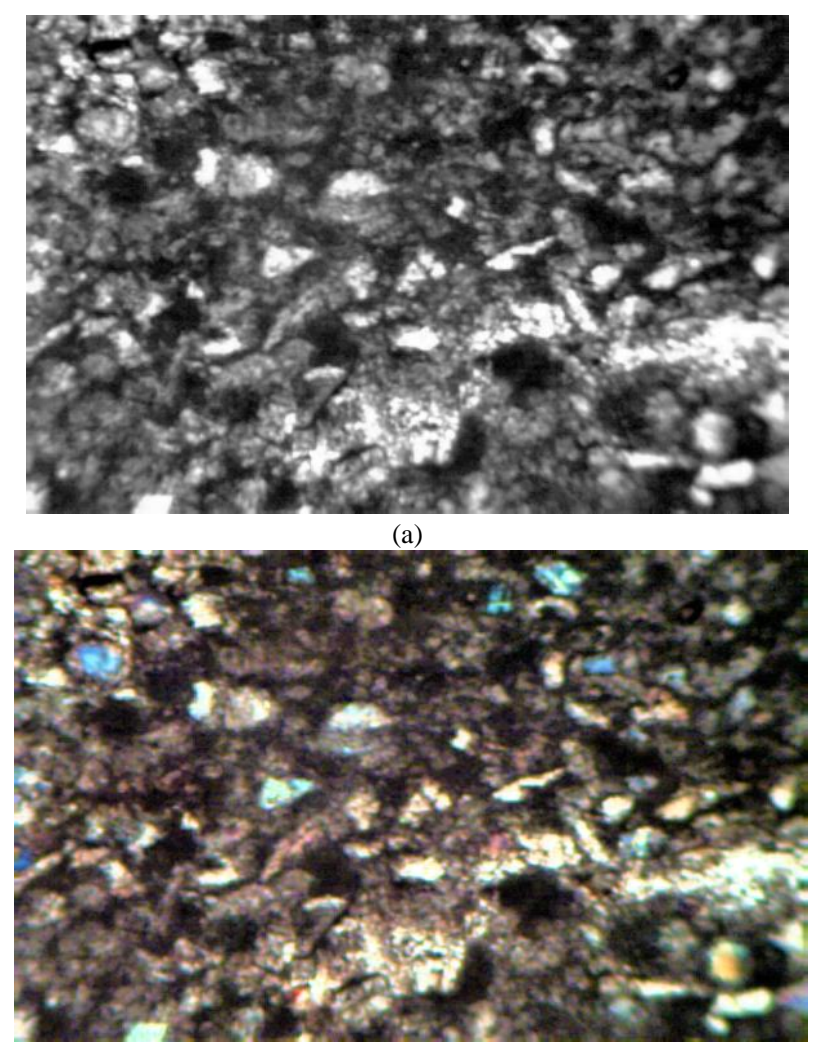

(b)

Fig 12F. Photomicrograph of ABS 5B under PPL (40X) (a) and XPL (40X) (b).
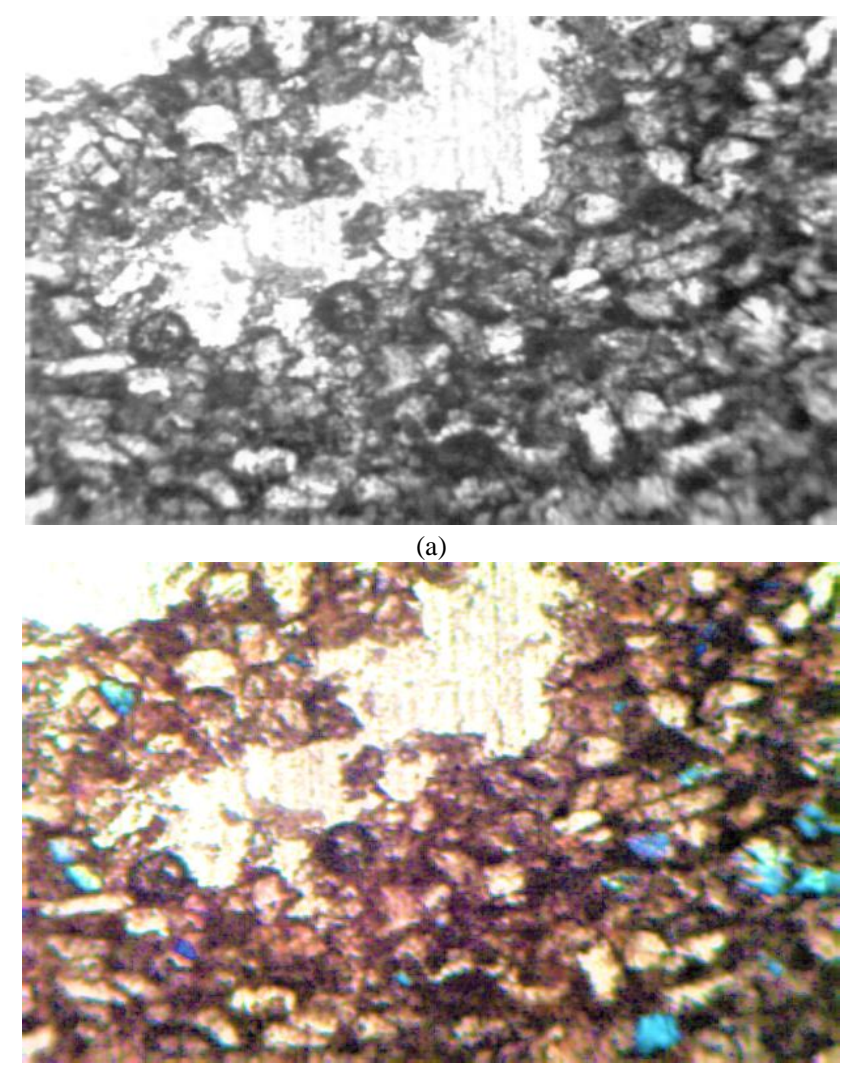

(b)

Fig. 12G. Photomicrograph of ABS 5mc under PPL (40X) (a) and XPL (40X) (b). 


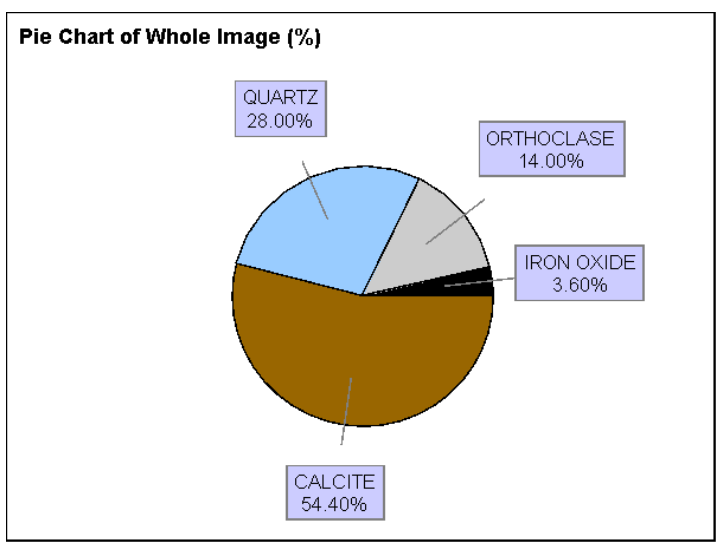

(a)

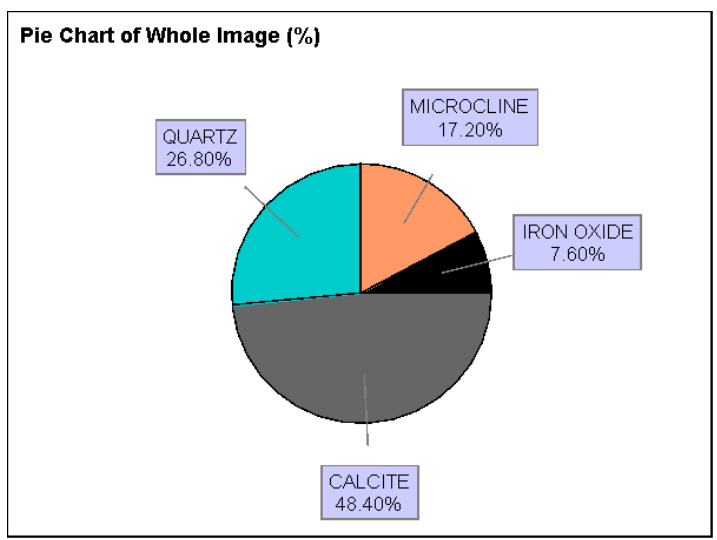

(b)

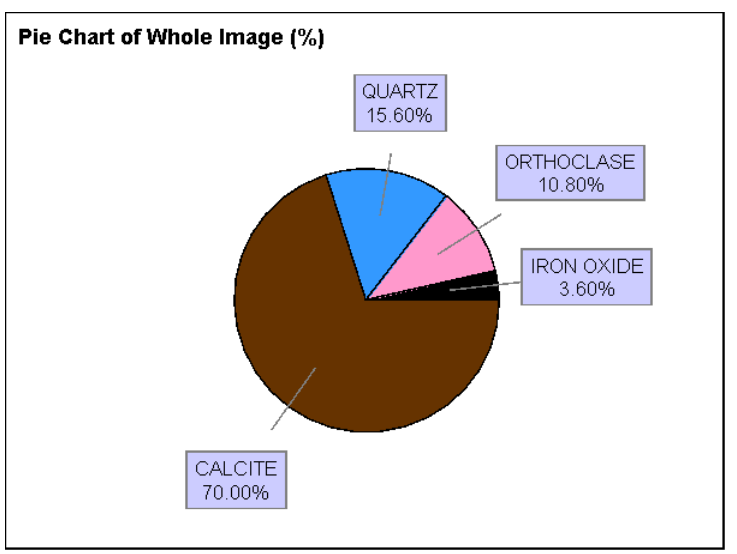

(c)

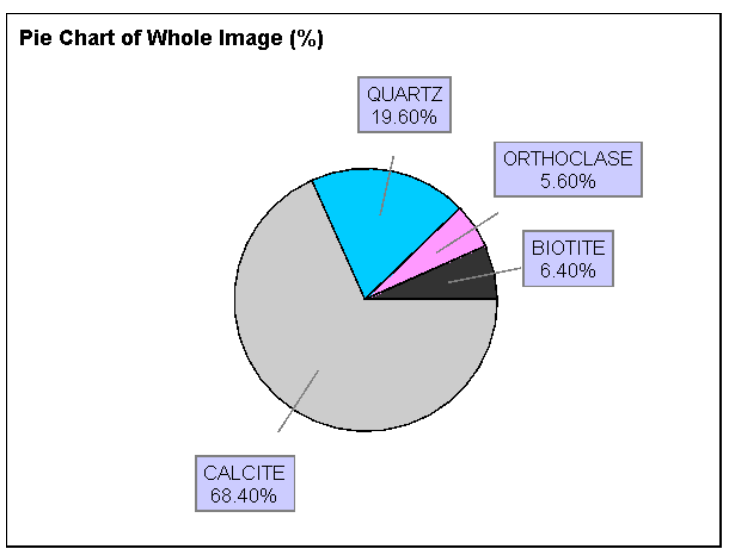

(d)

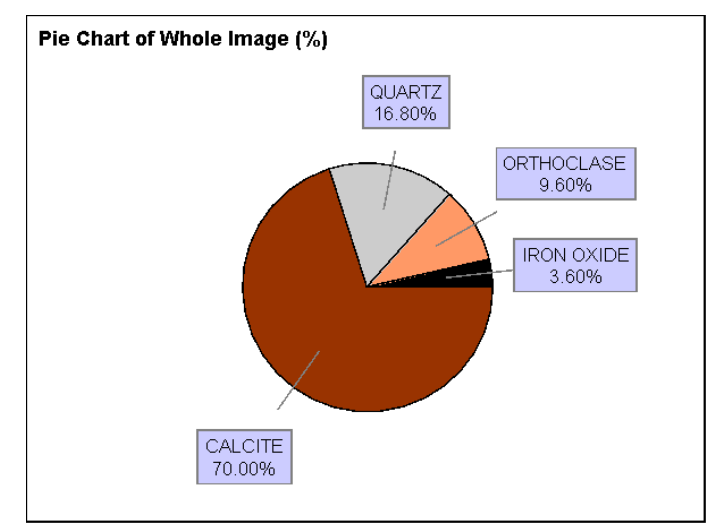

(e)
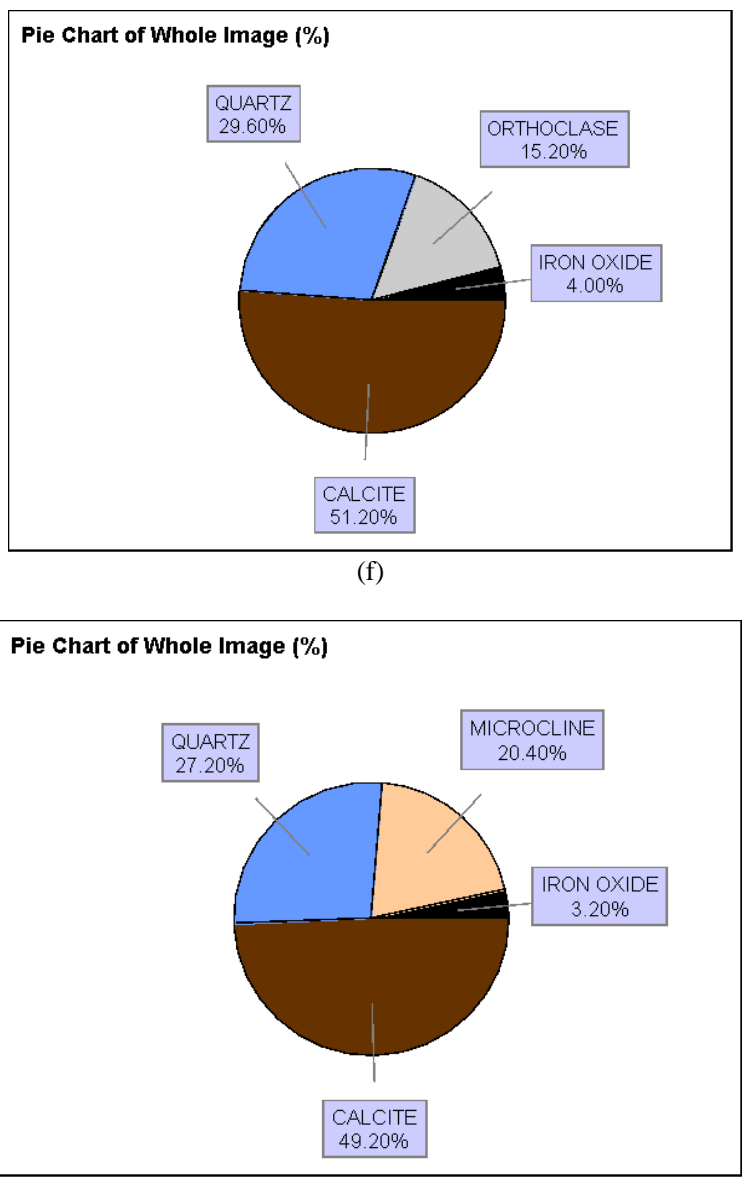

(g)

Fig. 13. Pie charts of mineral percentages under XPL: (a) ABS 1; (b) ABS 2; (c) ABS2B; (d) ABS3B; (e) ABS4B; (f) ABS5B; (g) ABS 5mc.

\section{SUMMARY}

Based on the results from XRD and the petrographic analysis, it is shown that the Amasiri Sandstone ridge outcropping at Abini has very high content of calcite, with an average calcite value of $51.39 \%$. Calcite occurs as skeletal particles and as sparry calcite that occurs as replacement for the quartz grains as well as cementing material in the Formation. Silica occurring as monocrystalline and polycrystalline quartz has an average value of $17.22 \%$. The point counter readings from the petrographic analysis also confirm this mineralogy. The quantitative analysis of the components of the Formation was done using the point counting mechanism which gave the values in percentages of the component minerals - 
quartz, calcite, orthoclase, microcline and iron oxide. Their various values are listed in Table X. Calcite has an average of $58.8 \%$, quartz has an average value of $23.37 \%$, orthoclase and microcline have a value of $13.26 \%$ and Iron Oxide has a value of $4.57 \%$. This mineralogy qualifies the Amasiri Sandstone occurring in Abini to be designated as Calcarenaceous Sandstone instead of Calcareous Sandstone as was proposed by [6]. According to [2], calcarenaceous sandstones occur in carbonate environment where there is a lot of influx of clastic materials and they would grade laterally into limestone or purer sandstone. [12] had opined that the Amasiri Sandstone ridge in Abini must have been deposited in a storm dominated shallow shelf distributary mount submarine bar, which is a favourable carbonate environment, and terrigeneous clastic materials may have been derived from the Oban Massif and the Cameroun mountains in the SE as was indicated from the paleocurrent direction. The angularity of grains also confirms a short distance of transport.

\section{REFERENCES}

[1] Pettijohn FJ. Sedimentary rocks, Third edition, CBS publishers and distributors, 2004.

[2] Doyle Larry J. Roberts, Harry H. Editors. Carbonate clastic transition (Developments in sedimentology). Published by Elsevier Science Publishers., Amsterdam, Oxford et. al. (1988) ISBN 10: 0444429042 ISBN 13: 9780444429049.

[3] Simpson, A. The Nigerian coalfield: Geology of parts of Onitsha, Owerri and Benue provinces. Bull. GSN, 1995;24:85.

[4] Murat RC. Stratigraphy and paleogeography of Cretaceous Lower Tertiary in southern Nig. African Geol. TFJ. Dessauvagie and MD. Whiteman (Ed), University of Ibadan press, 1972, 251-268.

[5] Umeji OP. Ammonite palaeoecology of the Ezeaku Formation, southeastern Nigeria. Journal of Mining and Geology, 1984, vol. 21, pp 55-59.

[6] Ekueme BN, Nyong EE, Peters,SW. Geological excursion guidebook to Oban Massif, Calabar Flank and Mamfe Embayment. Dec-Ford Publishers, Calabar, 1995.

[7] Akpofure E. and Didei SI. Sedimentology of the Turonian Ezeaku Sandstone in the Afikpo Basin, Nigeria. International Journal Geology and Mining, 2018; 4(2):211-223.

[8] Hoque M. Petrographic differentiation of tectonically controlled Cretaceous sedimentary cycles, South Nigeria. Journal of Sedimentary Geology, 1977; 17:235-245.

[9] Reyment RA. Aspects of geology of Nigeria. Ibadan university press, 1965, p. 133.

[10] Nwajide CS. Geology of Nigeria's sedimentary basins. Lagos, CSS Press, 2013.

[11] Peters SW, Nyong EE, Akpan EB, Essien NU. Lithostratigraphic revision for the Calabar Flank, SE Nigeria. In Proc. of the $31^{\text {st }}$ Ann. Conf. of NMGS.

[12] Amajor LC. The Eze-Aku Sandstone ridges (Turonian) of southeastern Nigeria. A re-interpretation of their depositional origin. Nigerian Journal of mining and Geology, 1987;23(1\&2):19-26. 